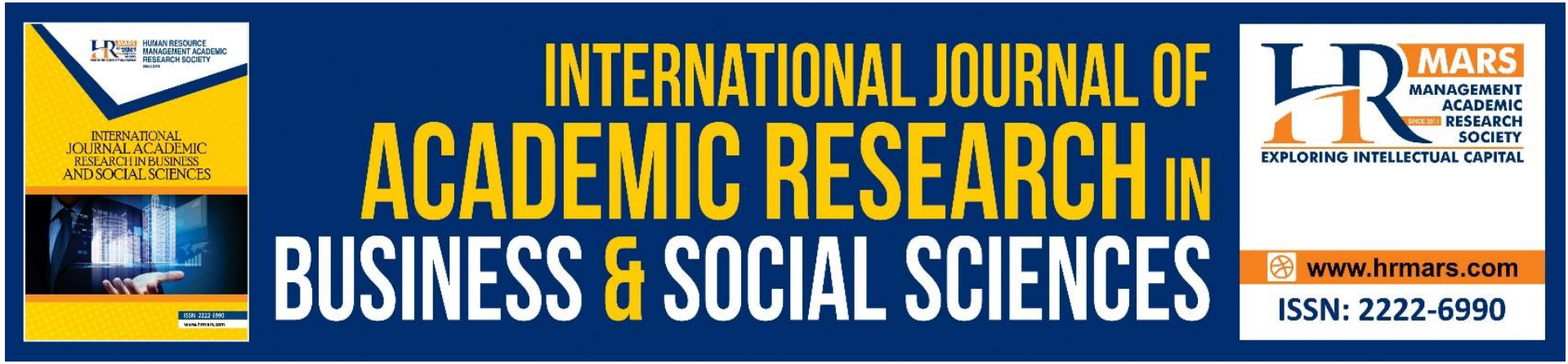

\title{
Level of Job Satisfaction and Level of Organizational Citizenship Behavior among Lecturers of The Islamic University of Melaka College
}

Baharuddin Puteh, Muhammad Yasin Omar Mokhtar, Ahmad Zulfandi Ibrahim, Wan Norhayati Wan Othman \& Syarifah Syarina Sheikh Kamaruzaman

To Link this Article: http://dx.doi.org/10.6007/IJARBSS/v11-i7/10545

DOI:10.6007/IJARBSS/v11-i7/10545

Received: 16 May 2021, Revised: 20 June 2021, Accepted: 11 July 2021

Published Online: 24 July 2021

In-Text Citation: (Puteh et al., 2021)

To Cite this Article: Puteh, B., Mokhtar, M. Y. O., Ibrahim, A. Z., Othman, W. N. W., \& Kamaruzaman, S. S. S. (2021). Level of Job Satisfaction and Level of Organizational Citizenship Behavior among Lecturers of The Islamic University of Melaka College. International Journal of Academic Research in Business and Social Sciences, 11(7), 907-915.

Copyright: @ 2021 The Author(s)

Published by Human Resource Management Academic Research Society (www.hrmars.com)

This article is published under the Creative Commons Attribution (CC BY 4.0) license. Anyone may reproduce, distribute, translate and create derivative works of this article (for both commercial and non-commercial purposes), subject to full attribution to the original publication and authors. The full terms of this license may be seen

at: http://creativecommons.org/licences/by/4.0/legalcode

Vol. 11, No. 7, 2021, Pg. 907 - 915

http://hrmars.com/index.php/pages/detail/IJARBSS

JOURNAL HOMEPAGE

Full Terms \& Conditions of access and use can be found at http://hrmars.com/index.php/pages/detail/publication-ethics 


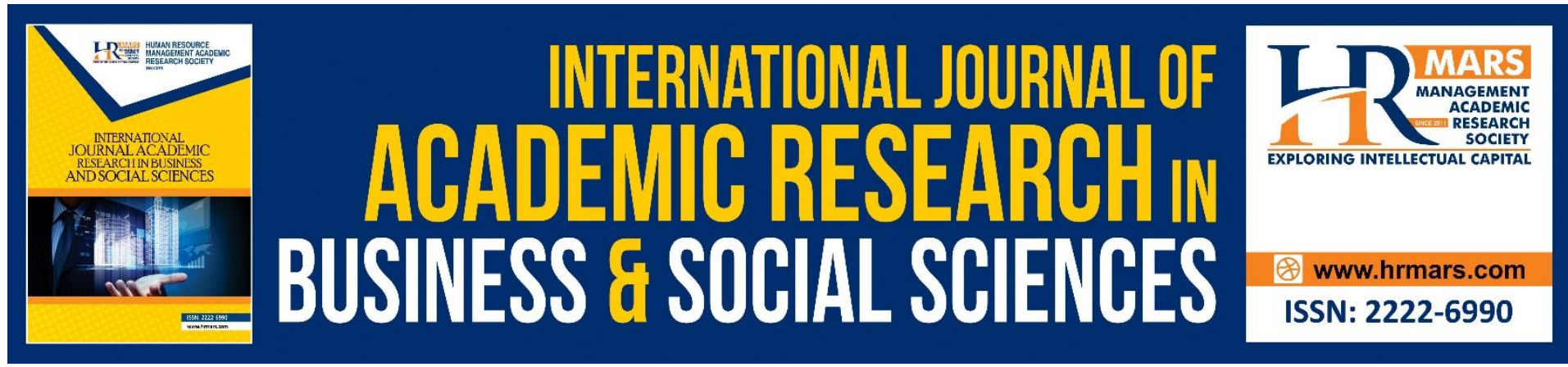

\title{
Level of Job Satisfaction and Level of Organizational Citizenship Behavior among Lecturers of The Islamic University of Melaka College
}

\author{
${ }^{1}$ Baharuddin Puteh, ${ }^{2}$ Muhammad Yasin Omar Mokhtar, ${ }^{3}$ Ahmad \\ Zulfandi Ibrahim, ${ }^{4}$ Wan Norhayati Wan Othman \& ${ }^{5}$ Syarifah \\ Syarina Sheikh Kamaruzaman \\ 1, ${ }^{3}$ Faculty of Languages \& Education Kolej Universiti Islam Melaka, Malaysia, ${ }^{2}$ Research \\ Management Centre Kolej Universiti Islam Melaka, Malaysia, ${ }^{4}$ Faculty of Educational \\ Studies, Universiti Putra Malaysia, Malaysia, ${ }^{5}$ Sekolah Menengah Kebangsaan Terendak, \\ Malaysia
}

\begin{abstract}
In the daily work of lecturers, they are bound to face several aspects such as students, documentations and KUIM, having the status of a private University Colleges they also have to deal with the admission of students which is one of their annual KPIs. This will definitely affect the lecturers both in the short and long term. Therefore, the behavior that needs to be demanded and possessed such as Organizational Citizenship Behavior (TKO) is actually able to create a good work ethic for an employee. As such, this study focuses on the findings that look into the TKO level and job satisfaction of KUIM lecturers. The results showed a high level of TKO but the level of work satisfaction was moderate. These findings could be further extended into details for there are more researchers that could be taken into account. These findings could be utilized by the Human Resources department for planning and developing suitable trainings and courses.
\end{abstract}

Keywords: Job Satisfaction, Organizational Citizenship Behavior

\section{Introduction}

According to Ehido et. al (2019) the success of education sector depends on the involvement, effort and contributions of academic staff as well as their professional capabilities. The job of Malaysian academic members has become more challenging due to the terms in fulfilling the key performance indicator and continuous demands from the university as well as other benefiting party in producing excellent graduates who are able to work in this country (Darus \& Ahmad, 2016)

Education field is amongst the most challenging field in our country. Education field put pressure on lecturers to give 'extra role behavior' in aiding the organization to achieve the highest level especially lecturers in the private sector (IPTS) such as those of the University 
College status. As commonly known, when an IPTS achieve the University College status, the IPTS needs to maintain their score in several criteria that is required whilst at the same time the IPTS would surely aim to achieve the status of being a full University based on their planning. As such, surely their lecturers would be bombarded with various jobs and extra roles in helping them to realize their aims and goals in becoming full University

In the Malaysia Education Blueprint 2015 - 2025 that was issued by the Ministry of Higher Education it had been outlined that the quality of Higher education institutions (IPT) could excel if its academic community excel as well. Academic community comprises of educators, researchers, head of institution, professionals, administrators and supporting staff. Proper administration is crucial for the optimum operation of an institution and its development. In other words KPT strongly suggests that the human capital available in an organization should be competent and aggressive to help empower educational organizations to remain relevant and to compete with existing HEIs (IPT).

Based on previous studies, job satisfaction is defined as positive feelings that arise after completing tasks or work. That positive feeling is able to drive an individual to work harder without feeling burnt out. Robbin (1989) individuals with high level of job satisfaction will remain constantly positive in fulfilling tasks that are assigned to them. As such, this job satisfaction comes with the involvement of individuals in their job. The job satisfaction factor can be classified into environment and atmosphere of work, carrier advancement and wages increment opportunity as well as colleagues. This factor is taken based on the Job description index designed by Smith et. al (1975) that was translated into Bahasa Melayu by (Konting, 1990).

Previous study by Fatmasari et al (2018) on the role of teacher motivation and their job satisfaction in their commitment toward the organization at special at special school indicated that job satisfaction and job motivation are closely related to one another. This study was conducted to investigate the role of teacher motivation as well as their job satisfaction in performing their tasks. The findings identified that job motivation poses more significant influence compared to job satisfaction in their commitment. However, it is undeniable that job motivation and job satisfaction are something that is necessary in a teacher to overcome the problems in their particular organization.

According to another research, individuals with low job satisfaction will give negative impact on the organization. The findings of this study is supported by the theory of Colquit, LePine and Wesson (2009), in their study entitled "Integrative Model of Organizational Behavior" where the emphasized that job satisfaction in an individual influences their commitment to their job organization.

Whereas Porter and Lawler (1968) in their research suggests the structuring of the work environment so that effective performance will lead to a combination of intrinsic and extrinsic motivation, which in turn will result in utmost job satisfaction.

This can be achieved by diversifying work to make it more interesting, and thus more intrinsically rewarding, and by making extrinsic rewards such as higher salaries and promotions clearly contingent on impressive performance

Amongst other related studies was one by Aslamiah et al (2019) where the study identified the role of principal and teacher's performance as well as whether or not teacher motivation and job satisfaction influences their performance. Various variables related to job satisfaction was used to measure the findings was divided into three dimensions which are extrinsic where the satisfaction comes with the reward received, intrinsic where the satisfaction comes in the form of personal feelings of the particular individual when they achieve something and 
experience utmost satisfaction. The hypothesis was proven in their study whereby there is a connection between job satisfaction and teacher's job performance. Based on this research it is confirmed that job satisfaction plays an important role in an individuals' work from the aspect of job performance and their motivation to offer their best.

Job satisfaction could help prevent individuals from being stressed or pressured in their job (Indah \& Amir, 2018). Reddy (2007) also backed this statement by expressing that job satisfaction is satisfaction that is obtained after completing a work process and it can be seen through the adjustment between the needs of the job and the surrounding climate. Job satisfaction makes an individual feel happy with their job and thus they will be free from stress.

Hoppock (1935) was the first individual who provided the definition of job satisfaction in the light of the combination between psychological state, physical and environment that makes an individual state "I am satisfied with my work". Moving forward, Herzberg (1959) in his theory stated that job satisfaction is a trait and a positive feeling that is present in an employee towards the job that they do. Whereas Benjamin and Melissa (1998) stated that job satisfaction is an approach including differences in individual aspects, needs or comparative values of the work done and how the task is carried out.

According to Graham (1998), job satisfaction is closely related to the relationship between a good work environment and individual work needs. In addition, Staines and Quin (1976) also defined job satisfaction as an overall assessment of a task and the various opinions that many made indicated that everyone liked their job. In fact, job satisfaction is important and has a correlation with one's job performance. High job performance will influence high levels of job satisfaction and indirectly reduce cases of resignation and absenteeism (Lawler \& Porter, 1967). Thus, in this study, researchers want to use the concept of job satisfaction proposed by Hart (1999) that there are two fractions of satisfaction, namely intrinsic job satisfaction and extrinsic job satisfaction.

\section{Problem Statement}

In the daily work of lecturers, they are bound to face several aspects such as students, documentations and KUIM, having the status of a private University Colleges they also have to deal with the admission of students which is one of their annual KPIs. This will definitely affect the lecturers both in the short and long term. If this is not handled well by the lecturers, over the course of time it will become a burden in their everyday lives. Lecturers need to ensure that their work environment is at good state. Surely employers need to provide work environment that is of satisfying quality to their employees. According to the Deputy Minister of Human Resources in 2018, Datuk Seri Ismail Abdul Mutalib had once voiced that any employer who causes employees to be in a state of stress can be subject to legal actions. As such employees need to be sensitive to their rights and what they need to have. In other words, a good work environment is a must for an employee. The fact is their energy resources and expertise are much needed in mobilizing and producing the future leaders of the country's leadership.

Studies related to TKO had been carried out in abundance in Malaysia. However, their focus had been swayed more towards educators in the department of primary and secondary schools and there are several studies conducted among IPTA lecturers. TKO -related studies conducted by previous researchers found that the study sample did not focus on academic staff as well as the testing of all variables together as predictors of organizational citizenship 
behavior was not tested in one study. This is because, a career as a lecturer is now very challenging and stressful with an increasing workload and not focused solely on teaching but also involves in administrative matters and so on. The hectic lives experienced by academic staff causes the practice of organizational citizenship behavior to be increasingly rarely practiced by them (Ibrahim et. al., 2018).

\section{Study Objectives}

- What is the job satisfaction level of KUIM lecturers

- What is the level of organizational citizenship behavior of KUIM lecturers

\section{Previous Studies}

\section{Methodology}

This study involved 66 respondents who were amongst KUIM lecturers. The method used is in accordance with the technique of Tabachnick and Fidell (2007), a simple random sample where all Malay entrepreneurs of Small and Medium Enterprises (SMEs) have a more equal chance to be selected as a sample.

$$
\begin{gathered}
N>50+8(\mathrm{~m}) \\
N=\text { sample } \\
M=\text { number of variables } \\
N>50+8(2)=66 \text { people }
\end{gathered}
$$

Therefore, in total the researcher selected a total of 66 respondents randomly grouped in this study. The test instruments used and the number of items available in each question are stated in the table provided below.

Table 1: Study Instrument

\begin{tabular}{|l|c|}
\hline \multicolumn{1}{|c|}{ Aspect } & $\begin{array}{c}\text { Number of } \\
\text { Questions }\end{array}$ \\
\hline $\begin{array}{l}\text { Job Satisfaction } \\
\text { Minnesota Satisfaction Questionnaire that was constructed by } \\
\text { (Weiss et al, 1967) }\end{array}$ & 20 \\
\hline $\begin{array}{l}\text { Organizational Citizenship Behavior } \\
\text { Organisational Citizen Behavior (OCB) that was constructed by } \\
\text { Podsakoff et al. (1990). }\end{array}$ & 20 \\
\hline
\end{tabular}

\section{Findings}

\section{Min Level Analysis}

The analysis in this section aims to address the research objectives outlined in the previous chapter. The analysis was performed using a descriptive analysis method. Using this method, relevant data such as mean and standard deviation will be released. 
Table 2 : Interpretation of Mean Score (Davis, 1971)

\begin{tabular}{cc}
\hline Statement & Score \\
\hline High & $3.68-5.00$ \\
moderate & $2.34-3.67$ \\
low & $1.00-2.33$ \\
\hline
\end{tabular}

Table 3 : Min Level variable Analysis

\begin{tabular}{ccc}
\hline Variable & Min & Std. deviation \\
\hline Job Satisfaction & 3.334 & 0.600 \\
TKO & 3.921 & 0.373
\end{tabular}

The analysis in the table above shows that the knowledge variable shows mean $=4.311$, standard deviation $=0.425$. While the entrepreneurial success variable showed mean $=4.311$, standard deviation $=0.481$. The results of this descriptive analysis can be concluded that, according to the interpretation of Davis (1971) mean data, both variables are at a high level

\section{Discussion}

The level of job satisfaction amongst KUIM lecturers is found to be at a moderate level. Tahap Job satisfaction could prevent and individual from being stressed on their job (Indah \& Amir, 2018). Reddy (2007) had also backed this statement by stating that job satisfaction is the satisfaction obtained after the completion of a job process and it can be seen through the adjustment between the needs of the job and the surrounding climate. Job satisfaction makes an individual to feel happy with their job hence they will be free from stress. Robbin (1989) stated that individuals with high job satisfaction will always be positive in carrying out the tasks that have been assigned to them. Thus, this job satisfaction comes with the involvement of individuals with their jobs.

Accrding to Dyah et al (2013) job satisfaction has a positive influence and relationship with TKO. This is because if the employee is satisfied, the employee will not be calculative on the work and is willing to work in any situation. This is because; Dyah et al (2013) also mentioned that an employee will work diligently in completing the task well even if the task is beyond his responsibilities. Dyah et al (2013) also said that when job satisfaction, commitment, and being able to adapt well is present, an individual will be better prepared to perform the task and 
serve wholeheartedly to the job in an effort to improve organizational excellence and always support every change that occurs if the change is related to the organizational goals.

When this organizational citizenship behavior is exhibited in performing a task it causes the employee to have a sense of responsibility and commitment to his or her organization. Finally, it contributes to the improvement of work quality and productivity (Ibrahim et. al., 2018). Mokhtar et. al. (2019) said that a high level of citizenship behavior will cause lecturers to act voluntarily to perform their duties even if the work is outside the field of their work scope.

\section{Conclusion}

Job satisfaction and organizational citizenship behavior of every IPTS lecturer especially needs to be taken into account. It can be said that job satisfaction is affected by the factor of environment. As such, it might poses an impact on the organizational citizenship behavior. As for that, in the future a more comprehensve study needs to be conducted to study the relationship between job satisfaction on organizational citizenship behavior. In a fairly complex work environment, every lecturer requires voluntary behavior to maintain a good work environment and quality. Having the characteristics of altruism and superior courtesy is not an obligation but a necessity today. According to Zulkarnain \& Aziz (2018) for every job that is done we will feel the satisfaction if we are satisfied in completing it wholeheartedly which will consequently leads us to feel the meaning of the job that we do. When we are satisfied with what we do indirectly, we will volunteer to protect our organization in any way we can. That is one of the signs that the citizenship of our organization is at its best. According to Mokhtar et. al (2020) again, the profitability and effectiveness of an organization depends on the level of practice of this behavior. If the practice of this behavior is at a high level it will benefit an organization and vice versa if it fails to be implemented the organization fails to reach a level of balance and will continue to be at a loss. The human resource management division of an organization plays a big role and is responsible for planning a competent staff development plan to increase the level of TKO in each employee, especially the lecturers.

The findings of this study can be used by the KUIM human resources office in exploring the types of training options that can be implemented for lecturers. the work ethic and organizational citizenship behavior of the lecturers are always at their best. In addition, this study is a pioneer for future researchers. Through the findings of this study, this study may be further developed through the addition of other more significant predictors. Hopefully this study is constantly improved from time to time.

\section{Acknowledgement}

This research is the result of a study from the KUIM Non -Funded Research Grant (GPTD).

\section{Corresponding Author}

Ahmad Zulfandi Ibrahim

Fakulti Pendidikan \& Bahasa

Email: ahmadzulfandi@kuim.edu.my 


\section{References}

Benjamin, P., \& Melissa, W. (2001). Emotional intelligent and affective leadership. Journal of Leadership and Organizational Development, 2, 5-10.

Colquitt, J. A., LePine, J. A., \& Wesson, M. J. (2009). Organizational behavior: improving performance and commitment in the workplace. New York: McGraw-Hill.

Darus A., Ahmad, F. (2016). Work stress, pay satisfaction, psychological empowerment and organizational commitment among academic staff. IJMS. 2016; 23(1):51-72.

Ehido, A. , Halim, B. A., Awang, Z. (2019). International Journal of Humanities and Social Science Research ISSN: 2455-2070; Impact Factor: RJIF 5.22 Received: 12-06-2019; Accepted: 14-07-2019 www.socialsciencejournal.in Volume 5; Issue 5; September 2019; Page No. 71-76Volume 5; Issue 5; September 2019; Page No. 71-76

Graham, M. W., \& Messner, P. E. (1998). Principals and job satisfaction. International Journal of Educational Management, 12(5), 196 - 202.

Hart, P. M. (1999). Predicting employee life satisfaction: a coherent model of personality, work, and nonwork experiences, and domain satisfactions. Journal of Applied Psychology, 84, 564-584.

Herzberg, F., Mausner, B., \& Snyderman, B. B. (1959). The motivation to work (2nd Ed.). New York: John Wiley.

Herzberg, F., Mausner, B., \& Snyderman, B. B. (1959). The motivation to work (2nd Ed.). New York: John Wiley.

Hoppock, R., \& Spiegler, S. (1935). Job satisfaction. Occupations: The Vocational Guidance Journal, 16(7), 636-643.

Ibrahim, M. A., Sulaiman, W. S. W., \& Hafidz, M. S. W. (2018). Organizational citizenship behavior as a mediator in the relationship between job satisfaction and organizational commitment towards task performance among university lecturers. Sains Humanika, 10(3), 47-56.

Konting, M. M. (1990). “Kaedah Penyelidikan Pendidikan." Kuala Lumpur: Dewan Bahasa Dan Pustaka.

Lawler, E. E. III., \& Porter, L. W. (1967). The effect of performance on job satisfaction, industrial relations. Industrial Relations: A Journal of Economy and Society, 7(1), 20-28.

Mokhtar, M. Y. O., Arifain, S. M. K., \& Isa, M. F. M. (2019). Tahap Tingkahlaku Kewargaan Organisasi (TKO) Dalam Kalangan Pensyarah Kolej Universiti Islam Melaka. Kolokium Penyelidikan Siswazah Kebangsaan, 110-119, eISBN 978-967-17258-5-6

Mokhtar, M. Y. O., Isa, M. F. M., Arifain, S. M. K., Jailani, A. I., \& Othman, W. N. W. (2020). The Concept of Altruism and Ihsan as an Approach towards Achieving Psychological WellBeing at The Workplace: An Observation at The Islamic University College of Melaka. International Journal of Academic Research in Business and Social Sciences. 10(10), 637648.

Podsakoff, P. M., MacKenzie, S. B., Moorman, R. H., Fetter, R. (1990)Transformational leader behaviours and their effects on follower's trust in leader, satisfaction, and organizational citizenship behaviour Leadership Quarterly, 1 , pp. 107-142

Porter, L., \& Lawler, E. (1968). Antecedent attitudes of effective managerial performance. Journal Organizational Behavior and Human Performance, 2(2), 122-142.

Rini, D. P., Rusdarti \& Suparju. (2013). Pengaruh Komitmen Organisasi Terhadap Organizational Citizenship Behavior (OCB) (Studi pada PT. Plasa Simpanglima Semarang). Jurnal IImiah Dinamika Ekonomi dan Bisnis. Vol.1, No. 1

Smith, M. S., Freeman, M. E., and Neill, J. D. (1975) Endocrinology 46,219-227. 
Staines, Q. R. (1976). American workers evaluate the quality of their jobs. Monthly Labour Review, 102(1), 3-12.

Staines, Q. R. (1976). American workers evaluate the quality of their jobs. Monthly Labour Review 102(1), 3-12.

Zulkarnain, N., \& Aziz, S. F. A. (2018) Faktor yang Mempengaruhi Tingkahlaku Kewargaan Organisasi Para Guru dan Kakitangan Sekolah di Negeri Sembilan, Jurnal Wacana Sarjana, Vol.2(4) Dis2018: 1-7 